\title{
The Digital Marketing Power of Transmedia: Applying Keller's Brand Resonance Pyramid to the Marvel Cinematic Universe
}

Stuart Francis *

DOI: https://doi.org/10.17230/9789587206289ch13

Pericles 'asher' Rospigliosi **

Bruce Samuel ***

\section{Introduction}

Historically, brands are a fairly recent phenomenon in the entertainment industry. Just a few early films became sequels, and most remained largely as standalone stories developed without thought for subsequent extension or commercial exploitation beyond their initial releases. The product was also linear: a passive experience that consumers watched from start-tomiddle-to-end with no personal interaction or influence.

Successful film promotion was geared towards the crucial first weekend of release by raising consumer awareness via a "push" approach: making consumers conscious about the product via direct communications methodologies such as advertising, or incentivising a cinema visit via promotions such as pre-screenings. Positive word-of-mouth (WOM) was crucial in raising awareness of a film to ensure its retention in cinemas beyond the opening weekend.

Major releases such as the early films in the Batman franchise enjoyed large advertising campaigns funded by high marketing budgets justified by large potential audiences. Low-budget or specialist films appealing to niche audiences were unable to justify high "marketing expenditures" and relied on word-of-mouth (WOM) generated by traditional film publicity techniques, i.e. pre-screenings promoted or two-for-one ticket offers.

" Senior Lecturer at Brighton Business School, University of Brighton, England. Email: s.francis2@brighton.ac.uk

** Bachelor in Applied Psychology and Computing from Bournemouth University, England. Principal Lecturer at Brighton Business School, University of Brighton, England. Email: a.rospigliosi@brighton.ac.uk

*** MBA at Brighton Business School, University of Brighton, England. Email: bas4@brighton.ac.uk 
Such techniques were broad, slow and offered little scope for the precise targeting required by specialist films with narrow audiences.

This paper offers a practical and theoretical contribution to understanding development and marketing of rich intellectual properties (IP) in the entertainment industry, such as films, television programs, comics and games. The impact of digital will be specifically considered. Using a case study of the successful Marvel films, featuring characters such as Iron Man, Thor and The Avengers, the paper aims to show that current ideas about brand equity can be applied. Through a critical analysis of the success (or otherwise) of the marketing of such products, the paper utilizes a leading brand exponent -Kevin Keller- on the importance of Customer Brand Equity. Applying Keller's (2009) 'Brand Resonance Pyramid' (BRP) to entertainment industry IP produces different, but complimentary findings to the paradigm of product development, to which the BRP has been previously applied. How to market IP in the entertainment industry needs to be considered due to the rapid technological changes in how IP assets are created and accessed, and the changes in audience and associated buying behaviour where media IP products are driven by globalised audiences who engage digitally.

Reaching high levels of brand resonance at the apex of Keller's pyramid means satisfying the key requirements of loyalty, attachment, community and engagement. Marvel films achieve this by drawing on the concept of Transmedia (Jenkins, 2006), which stresses a narrative thread that moves across multiple platforms, and where it offers an analysis that considers both IP content and the form. Marvel films sell characters with sets of narratives stretching back fifty years and that are globally consumed across a range of mediums. They have a 'roadmap' of over a dozen films planned for the next decade which will mutually reinforce each other's brand equity to mitigate the costs and risk of developing new IP and the ability/need to exploit a franchise frequently across digital channels.

The paper will consider implications for theory and practise on how ideas of transmedia might enrich and inform the brand equity of other IP assets and suggests an agenda for future research. 


\section{The Changing Digital Entertainment Environment}

The entertainment industry has experienced a high degree of "creative destruction" as a consequence of the digital process. Films, TV and gaming content is increasingly created and delivered online and is disrupting previously successful business models. The music industry has seen an established, viable and highly successful commercial model largely disappear and revenues dramatically reduced as consumers have increasingly sourced, downloaded and utilised content-often without paying.

Though a new revenue source for music has begun to appear via digital downloads or streaming, it is insecure and does not provide a certainty of business model or previously enjoyed levels of revenue. In Film TV and games, the downloading and distribution of content via effective peer-topeer file sharing and increased broadband capability is forcing commercial operators to explore the ability to maintain and protect existing brands, and to identify new business models to create sustainable revenue streams in the face of profoundly changing consumer behaviour. "Digital Natives" or Millennials increasingly see mobile platforms as their first stop for entertainment products.

Developments in digital distribution channels

There have been three principal areas of development for the digital distribution of music, film and TV.

Copy protected downloads were initially favoured by music companies (Romer, 2002), but low level take up and complaints about technological incompatibility, added to paid content access limitations, reduced industry enthusiasm (Barnett, 2007). Subscription streaming music services are significantly showing more success with services like Apple Music and Spotify, which increase their market share. While these services are showing some Return on Investment (ROI) potential, revenues remain smaller and returns to artists less than encouraging (Dredge, 2015). The free at point of delivery streaming services like YouTube, and Spotify's free version are more widely accessed, but as Dredge (2015) article shows, revenues for IP creators are normally small.

All this bodes poorly for a successful films and TV commercial distribution. The streaming services model experiences incompatibility and fragmented catalogues (Tennent, 2015), leading to customer 
dissatisfaction. Even the free-to-use (in the UK) BBC iPlayer is struggling to accrue legitimate users after an initial strong release (England, 2015). In addition, there is little scope for brand or commercial extension.

Globalisation developments in the entertainment industry

Other factors are influencing the launch of entertainment IP, particularly films. Recently, the release timescales and theatrical "window" for a film (the time between showing it in cinemas and its distribution as DVD and, now, online platforms) has reduced significantly, as entertainment companies seek to reduce the risk of piracy and take advantage of the preferred mode of distribution and access increasingly favoured by young consumers.

The effects of piracy -enhanced by the ability to easily and quickly copy and disseminate film and TV programming digitally- and the benefits of simultaneous, global film releases to amortise marketing costs-are driving the convergence towards global releases.

In addition, the emergence and growth of major new markets like China reflect the ongoing movement away from the US as the prime market, simultaneous with the development and production of indigenous IP that has -and must have-international potential. Films designed by Disney and Sony for the Chinese market, or with a strong Chinese cultural element reflect the move into local language films and TV shows (Shone, 2014).

As Millennials, or "digital natives", are more focused on consuming entertainment IP via digital platforms due to their preferred buying behaviour, the need to counter piracy and exploit the "long tail" revenues via a wider and more sustained distribution and product availability, means digital processes will further reinforce this approach. Netflix was projected to spend \$6bn on original content in 2017 (Goodfellow, 2017) and aims at building a subscriber base of 200 million in the near future (Duke, 2015). These developments mean that digital will become the key driver, and increasingly impact on the development of entertainment markets.

\section{Transmedia}

The marketing of the intangible brand facets, according to Shostack (1977), means the value offering will be defined by consensus realities and not by the external attributes of physical products. Therefore, the 
value of a film will be mediated or defined by the consumer's experience (Priem, 2007).

Transmedia conceptually enables an analysis of IP via the exploration of what happens to "stories told across multiple media" (Jenkins, Purushotma, Weigel, Clinton, \& Robison, 2009, p. 86). It is "a particular narrative structure that expands through both different languages (verbal, iconic, etc.) and media (cinema, comics, television, video games, etc.)" (Scolari, 2009, p. 587). Regarding the marketing of IP

it not only affects the text but also includes transformations in the production and consumption processes. Researchers and producers visualize new business opportunities for the media market as new generations of consumers develop the skills to deal with the flow of stories and become hunters of information from multiple sources (Scolari, 2009, p. 589; our emphasis).

The ability offered for consumers to digitally develop their own content for its incorporation into existing and future IP is key. By giving consumers the tools to produce User-Generated Content (UGC) they can directly develop, implement and contribute towards the development of IP interact and then influence its future direction.

The transmedia process is changing its form and the final outcome is highly uncertain and unpredictable. Past attempts have been made to combine linear and interactive entertainment forms, i.e. Fightbox, developed by $\mathrm{BBC}$ Worldwide to create a new and innovative entertainment format. However, the programme was not a success, with viewing figures hitting a high of only 56,000 and a low of 6.000 viewers, figures close to a zero rating in the BARB audience measurement system (The Guardian, 2003).

Consumer desire and demand to increasingly engage with and influence IP is incentivizing entertainment organisations to take advantage of the potential that transmedia theoretically offers, both creatively and commercially. However, commercial barriers such as organizational silos mean few are willing to risk losing money in their vertical (i.e. film) by investing in another vertical (e.g. online games).

The media industry therefore remains conservative. Major entertainment organizations like Disney and Warner Bros, whose operations cover all forms of mainstream media, remain focused on "franchises" but increasingly know that "transmedia" offers huge potential. 


\section{The Brand Resonance Pyramid and the entertainment industry}

We propose the application of an existing theoretical framework relating to developing brands repurposed in a digital context, in order to provide a (marketing) template for evaluating and developing new forms of commercial models and IP for entertainment brands in the digital age. It is important to identify the key marketing components of successful transmedia properties.

Keller's (2009) original Customer-Based Brand Equity (CBBE) model theory sought to understand brand building in terms of consumer knowledge structures, different brand development stages and the branding objectives at each stage.

The model consisted of four ascending steps (2009, p. 143):

i) Ensuring customer identification of the brand and cognitive association with a specific product class or customer need;

ii) Establishing brand meaning totality in the minds of consumers by strategically linking tangible and intangible brand associations;

iii) Eliciting appropriate customer responses in terms of brand-related judgement and feelings and;

iv) Converting brand response to create an intense, active loyalty relationship between customers and the brand.

These four steps reflect a pyramid of six brand building blocks with customers, consisting of rational (tangible) facets like product characteristics that meet basic consumer "needs" and emotional (intangible) facets that create a "want" via incorporated social approval, personality and, brand values and experiences (Keller, 2009).

Resonance is the ultimate objective of the pyramid: developing a relationship whereby consumers feel "in-sync" with the brand. Genuine one-to-one marketing and interaction with individual customers is achievable via digital platforms and makes the pyramid an appropriate model for application to digital brand development and subsequent evaluation. 
Figure 1. Customer-Based Brand Equity model pyramid (Keller, 2009)

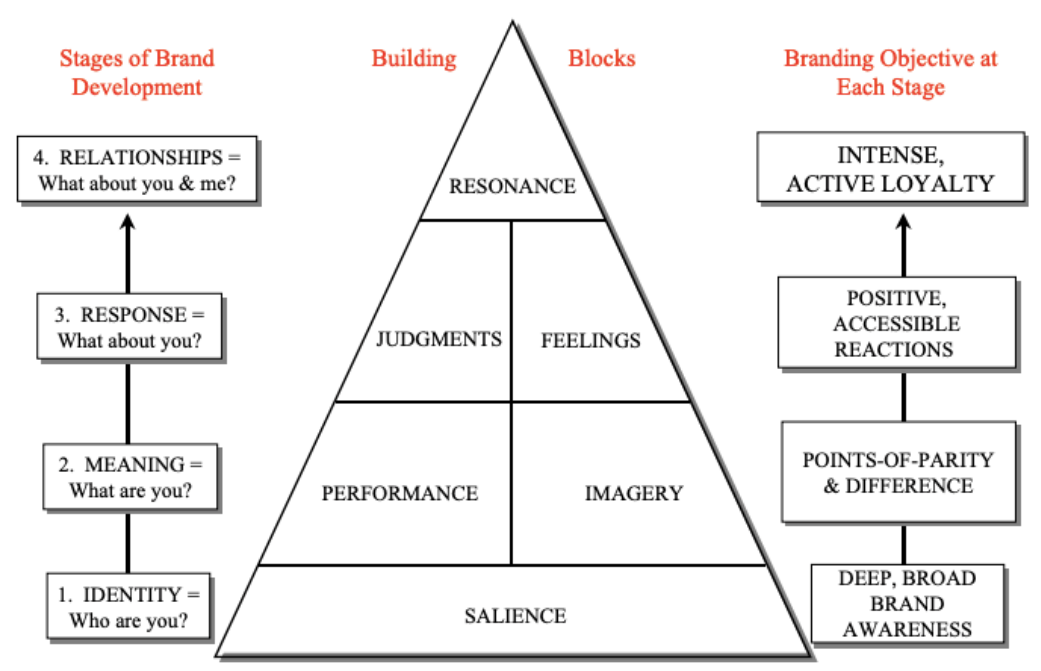

Source: Diagram reproduced from Keller (2009, p. 144).

Each stage of the pyramid assists in identifying the new brand building drivers to do so in a digital entertainment context.

1 Brand salience: how easy/often "customers think of the brand under various purchase or consumption situations" (Keller, 2009, p. 143).

The key brand development and brand objective at this stage is to create an identity and deep awareness. Young consumers are increasingly consuming entertainment IP via digital platforms. Buying and consumption behaviours are also changing fundamentally: for example, television programming is downloaded and watched later at a time of personal convenience.

Digital is also driving distribution saliently. Digital platforms, such as Netflix with films, are increasingly the preferred mode of access for entertainment IP a development that is presenting challenges in relation to illegal purchase and consumption patterns, such as accessing IP for free (Duke, 2015).

Developing, maintaining and retaining brand control and keeping salience across multiple platforms is a key challenge. 
2 Brand performance: how well is the product or service meeting the functional needs of the consumer (Keller, 2009, p. 143).

The move by the games industry towards online -and in particular- mobile gaming reflects this process. It also presents an opportunity to exploit The Long Tail by maintaining product availability indefinitely and to generate revenues over extended periods. The functional needs of both consumers and developers of IP are being affected by consumer preference to develop and influence IP via user-generated content (UGC) or to promote it via social media. The brand development objectives of entertainment companies involve retaining control of their IP identifying and building revenue streams whilst still satisfying the needs of the consumer in the digital era.

3 Brand imagery: "the extrinsic properties of the product of service" and how the brand "meets customer's psychological or social needs" (Keller, 2009, p. 143).

The pyramids objectives include performance and imagery stages to create meaning and establish points-of-difference $(\mathrm{PoD})$. The brand's associations must be meaningful to consumers and achieve differentiation to create preference. Digital is increasingly the focus for brand development, promotion and status for the millennial target audience.

4 Brand judgements: "focus on customers' own personal opinions and evaluations" (Keller, 2009, p. 143).

The growth and power of eWOM is hugely influencing brand judgements. Consumer ability to congregate in communities to discuss, state preference and create content via user-generate content is profoundly affecting the creative direction of storytelling and development of associated content.

eWOM is defined by Henning-Thurau, Gwinner, Walsh and Gremler (2004) as "any positive or negative statement made by potential, actual, or former customers about a product or company, which is made available to a multitude of people and institutions via the Internet" (2004, p. 39). Targeting Communities or Influencers is increasingly the preferred communications medium for entertainment marketers via effective eWOM, to rapidly disseminate positive opinion digitally. 
5 Brand feelings: what "are customers' emotional responses and reactions with respect to the brand"? (Keller, 2009, p. 143).

The key brand development objectives at the judgement and feelings stage are to induce a (positive) response from consumers and associated accessible reactions. Digital interactivity is increasingly enabling entertainment marketers to achieve this, whilst also presenting challenges in controlling and managing brand attributes and perceptions regarding the target audience.

6 Brand resonance: the nature of brand relationship customers have and the extent they feel "in-sync" with it (Keller, 2009, p. 144).

The key objective of the pyramid is to achieve brand resonance to reflect psychological depth and activity levels engendered by associated customer loyalty. Achieving resonance means companies can build symbiotic relationships with consumers and intense active loyalty via customer interactivity and engagement digitally.

Entertainment products are inherently emotional and involve "escapism" and the "suspension of disbelief". If resonance is achieved, it can potentially extend a brand into more product and media categories to reduce costs and strategic risk.

As Keller outlines, certain product categories potentially allow for more resonance due to higher interest and activity levels. Entertainment brands such as Marvel, with large followings, are synonymous with this, and digital is enhancing and further enabling this process to realise increased resonance levels.

New forms of (digital) creation, distribution, delivery and consumption of entertainment is making insightful analysis, evaluation and understanding of the relationship such consumer groups have with essential digital entertainment brands.

\section{Extending the Brand Pyramid: Developing Resonance in a Digital Context}

The amortisation of a brand by developing digital assets across emerging and different platforms means that transmedia conceptually presents a format that potentially offers new ways of engaging the core audience with entertainment IP and increase brand resonance. 
The resonance component of the pyramid is increasingly important, given the digitally orientated behaviour of the core entertainment audience and its preference for accessing content digitally. It also provides a relevant model to identify and evaluate future success factors in the digital era, in relation to the specific categories that resonance constitutes. These are:

\section{i) Behavioural loyalty}

Behavioural loyalty relates to repeated purchases and the amount or brand share of category volume or "share of category requirements": "how often and how much do customers purchase a brand?" (Keller, 2009, p. 145). Repeated brand purchases and of associated goods are central to the commercial success of entertainment organizations today.

Transmedia, brand development and exploitation across additional platforms offers major opportunities for entertainment companies to generate repeat purchases and value by extending the brand across new platforms, via digital's ability to increase personal attachment through interactivity, content creation and personal influence-key requirements to elevate resonance.

\section{ii) Attitudinal attachment}

Creating greater loyalty also requires deeper attitudinal attachment that is generated by developing marketing products that fully satisfy consumer needs. Participating in digital communities or developing usergenerated content (UGC) are pertinent examples. The loyalty, affiliation and devotion inherent in entertainment brand franchises such as Star Wars are central to ongoing brand investment. By demonstrating longevity and by being adopted by both older and emerging consumers means realising economies unavailable to new franchises. Digital engagement with a brand franchise reinforces loyalty via closer and deeper engagement.

iii) Sense of community

Identification with a brand community reflects an important social phenomenon: the feeling of "kinship or affiliation with [others] associated with [a] brand" (Keller, 2009, p. 145). These connections increasingly occur online around digital communities who engage, interact, discuss and disseminate views and opinion globally as never before. 
The audience developed over time for brands like Star Trek via Trekkies is manifested online in the context of communities. The ability to meet, interact, influence and contribute to a brand in real-time significantly enhances the ability to lock customers to the franchise.

The time and energy devoted by true Batman aficionados is immense and provides a powerful form of loyalty and promotion for the brand. eWOM promulgates this effect, and speed of diffusion exaggerates this attribute. The success of the "Why So Serious" transmedia campaign that went viral for Batman: The Dark Knight demonstrates the power and importance of a community for the effective marketing of a film franchise.

iv) Active engagement

The stronger sense of community among fan-bases engenders real loyalty to a brand and favourable intentions. This reflects Keller assertion that strong affirmation of brand loyalty comes when customers invest time, energy, money and other resources in the brand beyond simple purchases $(2009$, p. 145).

Though interaction was possible in the pre-digital age in a very limited form, the ubiquity of digital devices such as mobiles has made interaction between consumers more prevalent and profound. As the Brand Resonance Pyramid outlines, customers can now invest greater time and personal resources beyond that expended during consumption previously. Digital communications and communities offer club membership, regular updates, engagement via ongoing dialogues with fellow aficionados and the potential to act as brand ambassadors.

\section{A Transmedia Case Study to Demonstrate the Impact of Brand Resonance: The Marvel Universe}

The Marvel Cinematic Universe (MCU) describes a range of media offerings. The content originated from a range of comics published by Marvel since the early 1960s. Since the first appearance of the Fantastic Four, the range of outputs has included not just comics and films, but books, records, magazine, clothes and animated and live action television content. While this vast range of content forms a backdrop to the analysis of transmedia as a way of developing and cross promoting products, forthcoming analysis focuses on the current and planned MCU, initiated by the Iron Man release in 2008. 
MCU sought to develop a single coherent and integrated universe. The initial sixteen movies featured Marvel characters but little significant incentives to create any inter-textual or transmedia integration. While these IPwere used to successfully spin-off tie-in products, they did little to develop an audience's awareness of the other characters in the Marvel universe (Johnson, 2012). However, the success of the movies produced in the early 2000s gave Marvel the financial position to directly control production with editorial oversight from the comic book managers (Johnson, 2012).

The movies demonstrated an orchestration of plot and characters across individual movies similar to the published comics and previous iterations of superhero movies. For example, The Avengers (2012) featured characters Thor, Hulk, Captain America and Iron Man, each of whom had been the lead in a film in the preceding three years. The increasingly interdependent plotting established a continuity and an inter-textual linkage that created "world building" and the unfolding of media franchises across many different media (Jenkins, 2006). Recent Marvel movies demonstrate strong facets of Universe building, such as Guardians of the Galaxy releases, set on planets far from Earth, yet featuring characters, motivations and events in the same 'universe' as in the other Marvel movies.

\section{The Marvel Road Map}

This all-encompassing universe of Marvel continuity is fuelled by an accelerating rate of releases. However, the IP is being developed across other platforms. More than fifty episodes of live action television shows, animated television episodes and comics featuring Marvel Universe characters have been already developed.

Keller (1993) considers customer-based brand equity to be the "differential effect that a consumer's knowledge about a brand has on their response to marketing for that brand" $(1993$, p. 8). For the MCU, this relies on the recognition of the principal protagonists i.e. the hero or villain of any particular treatment.

Marvel IP's objective is to achieve brand equity not just via brand facts but also through "thoughts, feelings, perceptions, images, experiences" (Keller, 2009, p. 143). For this to happen, a number of brand pyramid steps need to be achieved. In the following application of the pyramid, particular attention will be paid to the transmedia characteristics of the 
Marvel Cinematic Universe, to highlight the particular value of a transmedia approach to the development of Customer Brand Equity in potential audiences for media content.

\section{The Marvel Cinema Universe and User Generated Content}

Marvel comics have a well-established cannon of user-generated content ranging from independently published comics fanzines, such as The Comicollector (Bails, 1965), to the annual ComiCon in San Diego, where major film releases are scheduled (Kamen, 2015).

Marvel Studios have promoted the importance of user-generated content in a range of innovative ways. The background stories that integrate the different characters, assembled in The Avengers, was released as a digital comic. Each character's origin was drawn by a fan, who had been offered the opportunity to create the art in a competition, using digital authoring tools (Farooq, 2015). This generated interest in the publication even before the release of inter-textual stories that drew together characters from different IP Fans were able to create origins which offered an easy entry point to any consumers. The winners were announced at ComicCon 2015 in San Diego.

Johnson analysed the value of fans and their world view (a form of virtual user generated content) and found that the existence of fans validated Marvel Studios' expertise in managing the IP of the Marvel Cinema Universe, meaning they were able to leverage this whilst retaining close control of the films (Johnson, 2012).

The MCU case shows how transmedia material is highly suited to marketing high value digital IP by analysing its characteristics in relation to marketing and the use of Keller's Brand Resonance Pyramid.

The Brand Resonance Pyramid builds on Keller's earlier CustomerBased Brand Equity Model, which considered customer-based brand equity to be the: "differential effect that a consumer's knowledge about a brand has on their response to marketing for that brand" (Keller, 1993, p. 8). For the MCU, this relies initially on the recognition of the principal protagonists of any particular treatment. The CBBE consists of six components: salience, performance, imagery, judgments, feelings and resonance.

It is the final pyramid part, Resonance, that is potentially the most relevant for transmedia. For Marvel IP to achieve brand equity and not just "the facts about the brand -but also the thoughts, feelings, perceptions, 
images, experiences" a number of steps need to be achieved, as outlined in the brand resonance pyramid. In this application of the pyramid, particular attention will be paid to the transmedia characteristics of the Marvel Cinematic Universe to highlight the particular value of a transmedia approach for the development of Customer Brand Equity in potential audiences for media content.

\section{Brand Resonance}

The four elements of the brand "resonance" component of the brand pyramid are all directly related to the characteristics of transmedia and the digital landscape. Consequently, "resonance" offers a specific sub-framework to evaluate core components of transmedia development and marketing.

\section{i) Loyalty}

The rapidly rising cost and risk associated with entertainment IP development makes longevity a key factor in the success of "universes".

Behavioural loyalty relates to repeated purchases and the amount of share of category volume a brand enjoys. To be profitable, a brand must be bought often and in volume to generate Customer-Lifetime Value (CLV).

By locking consumers into a brand, via digital technology/platforms, communications and communities transmedia offers the possibility of ongoing dialogue and interaction with a brand/IP

\section{ii) Attitudinal attachment}

Behavioural loyalty is necessary but not sufficient for resonance to occur. Consumers need to buy because of strong personal attachment, and not just to satisfy a basic "need". A brand needs to be viewed as special, and consumers need a positive "attitude" towards it.

Technology and transmedia "worlds" are facilitating dynamic brand communities, one-to-one immersion and the potential to contribute towards a brand via UGC.

\section{iii) Sense of Community}

Identification with a brand community may reflect an important social phenomenon whereby consumers feel kinship or affiliation with other people associated with the brand. Connections may involve fellow brand users, consumers or company representatives. 
Increasingly, these occur online. Digital is enabling large, global communities coalescing around brand franchises and fan-bases that connect consumers and assist in the development of "collective intelligences" or knowledge (brand) spaces. These will potentially be the source of new, emergent and dynamic UGC.

\section{iv) Active Engagement}

Brand affirmation loyalty is strongest when customers invest time, energy, money into the brand beyond just consumption -joining a club, receiving product updates or engaging in exchanges with community members. Digital communities are providing the means to really do this.

Marvel fans want not just to experience or purchase a brand, they want to participate, collaborate and contribute towards its development. Digital is the means of doing this; transmedia IP is the outcome.

Table 1. Applying Keller's Brand Resonance

Pyramid to the Marvel Cinematic Universe

Brand Salience

Stage 1: Identity: who are you

- What type of heroes/characters do you like?

- Psychological, Anti-Authority, Anti-Hero, Corporate or "Underdog"

Branding objective: Deep broad brand awareness

- Character and brand recognition

- Extend across platforms

- Comic association

- Link different characters

- Migrate movies to comics, TV, games and other digital content

TRANSMEDIA ELEMENTS:

- Brand platform extension

- Storyworld immersion -move into "fourth space"

- Link and contribute to multiple storylines

- Expand stories and develop new content characters

Keller's Sub-Dimensions:

CATEGORY IDENTIFICATION, NEEDS SATISFIED

- Films, Tv, Games Print, Digital/Online series

- "Got to have "em all"

- Completeness: "collectors museum"

- Customer escapism 
Brand Performance (rational)

Stage 2: Meaning: what are you?

- Character association

- Origin story

- Sequel linkage

- "Crossovers"

Branding objective: points of parity/difference

- Purchase levels

- Consumer "needs" satisfaction

- Awareness

TRANSMEDIA ELEMENTS:

- Brand, immersive engagement

- Community membership

- Participation and collaboration

- Loyalty program

Keller's Sub-Dimensions:

PRIMARY CHARACTERISTICS \& SECONDARY FEATURES, PRODUCT RELIABILITY, DURABILITY \& SERVICE ABILITY, SERVICE EFFECTIVENESS, EFFICIENCY, EMPATHY, STYLE \& DESIGN, PRICE

- Well-made films

- "Outside Directors"

- Creative Controllers

- Longevity

- Value

Brand Imagery (emotional)

Stage 2: Meaning: what are you?

- What aspects of the IP are you familiar with?

- What aspects are different from previous history, situations, usage?

Branding objective: points of parity/difference

- Brand name and attribute communication

- Distinctive appearance

- Consistency

TRANSMEDIA ELEMENTS:

- Do you want back-story?

- Origin re-tellings

- More about the characters

Keller's Sub-Dimensions:

USER PROFILES, PURCHASE \& USAGE SITUATIONS, PERSONALITY \& VALUES, HISTORY, HERITAGE, EXPERIENCES

User created images 
Brand Judgements (rational)

Stage 3: Response: what about you?

- Do previous movies and IP reassure you content will be high quality/credible?

- Do you care about the characters or the plot?

- How do you feel about the movie and characters?

- What story elements do you relate to?

Branding objective: positive accessible reactions

- Satisfies Marvel consumer "needs"

- Positive feedback

- Ongoing engagement

- Immersive experiences

TRANSMEDIA ELEMENTS:

- Immersion and participation

- Stories continue in comics, TV and other movies

- Brand extension into digital space

- Loyal fans demonstrate continuing resonance

Keller's sub dimensions:

QUALITY, CREDIBILITY, CONSIDERATION, SUPERIORITY

Different from other competitors and iterations?

Brand integrity

Positive eWOM 
Brand Feelings (emotional)

Stage 3: Response: what about you?

- How do you feel about the movie?

- How do you feel about the characters?

- What story elements do you relate to?

Branding objective: positive accessible reactions

- Is a "want" or desire being created?

- Brand community association

- Advocators and ambassadors

- Personal connection with IP

TRANSMEDIA ELEMENTS:

- Will consumers join the "community"?

- Will they want to participate and co-create?

- Stories followed in comics, on TV, or in other movies?

- Consumers demonstrate empathy and "brand attachment"

- Community affiliation

Keller's Sub-Dimensions:

WARMTH, FUN, EXCITEMENT, SECURITY, SOCIAL APPROVAL, SELF-RESPECT

- Social belonging

- Positive emotions

- The "feel good" factor

- Buzz

- Connection with peers

- "Sense of belonging" 
Brand Resonance

Stage 4: Relationships: what about you \& me?

- Do you share your excitement with peers?

- Do you follow the story between films in comics/games?

- Do you connect with the brand and fans via social media?

- Brands events, i.e. ComicCon

Branding objective: intense active loyalty

- Ready to share and act as advocate for the movie

- Extend market/brand lifecycles

- Brand/IP extensions

- Consumer data

TRANSMEDIA ELEMENTS:

- Digital "communities"

- Content co-creation

- Meet/interact with new fans

- Opinion sharing

- "Internal" (brand) marketing

Keller's Sub-Dimensions:

LOYALTY, ATTACHMENT, COMMUNITY, ENGAGEMENT

- Ongoing commitment

- Brand advocates/ "Influencers"

- Online participation

- Collaboration and participation

- The Marvel "Tribe"

Fans to super-fans

Source: Own elaboration based on the Sub-dimensions of brand building blocks (Keller, 2009), Building Strong Brands in a Modern Communications Environment, Journal of Marketing Communications, Vol. 15, num. 2-3, pp. 139-155. 


\section{Conclusion and Future Research}

The preceding analysis demonstrates the power and potential of digital marketing for an entertainment franchise in previously obtainable ways. Keller's Brand Pyramid offers a theoretical framework for the evaluation of potential transmedia IP and achieving brand resonance.

However, further research is needed in what is a rapidly developing and evolving context.

How do consumers influence an entertainment brand, precisely in a digital context: how can digital brand equity be created?

Via what digital outlets and communications do consumers prefer to engage with entertainment products and how can their inputs through these platforms exert influence on the IP?

How can brand resonance and associated relationships be deepened and enhanced going forward to create enhanced "loyalty" towards both major and niche franchises by exploiting the digital process?

How can transmedia storytelling be most effectively used across a range of digital platforms to increase IP brand resonance? 
Bails, J. (1965). America's Four-color Pastime. In The Guidebook to Comics Fandom. Glendale, CA: Bill Spicer.

Barnett, T. (2007). Interoperability Between Antitrust and Intellectual Property. George Mason Law Review, 14(4), 859-870. Retrieved from https://bit.ly/2QvfIRZ

Dredge, S. (2015, April 3). How much do musicians really make from Spotify, iTunes and YouTube? The Guardian. Retrieved from https://bit. ly/1qQHa0n

Duke, S. (2015, September 20). Now Netflix is Gunning for an Oscar. The Sunday Times. Retrieved from https://bit.ly/2sgq3HJ

England, L. (2015, May 14). The number of people watching shows on BBC iPlayer has dropped for the first time. Business Insider. Retrieved from https://read.bi/2SO00DH

Farooq, A. (2015, August 7). Adobe Students \#MakeThis with Marvel at SDCC 2015. Adobe for Education. Retrieved from https://adobe. ly/2SKcNXq

Goodfellow, J. (2017, June 20). Netflix trials personalised pre-roll video 'previews' to promote its original programming. The Drum.com. Retrieved from https://bit.ly/2CXHPpt

Henning-Thurau, T., Gwinner, K., Walsh, G., \& Gremler, D. (2004). Electronic Word-of-Mouth via Consumer Opinion Platforms: What Motivates Consumers to Articulate Themselves on the Internet? Journal of Interactive Marketing, 18(1), 38-52. Retrieved from https://bit.ly/2FjdCCF Jenkins, H. (2006). Convergence Culture: Where Old and New Media Collide. New York, NY: New York University Press.

Jenkins, H., Purushotma, R., Weigel, M., Clinton, K., \& Robison, A. J. (2009). Confronting the Challenges of Participatory Culture: Media education for the 21st century. Cambridge, MA; London, England: MIT Press. Available in https://bit.ly/2ENQPLi 
Johnson, D. (2012). Cinematic destiny: Marvel studios and the trade stories of industrial convergence. Cinema Journal, 52(1), 1-24. doi: 10.1353/cj.2012.0108

Kamen, M. (2015, July 13). The best trailers from San Diego Comic Con 2015. Wired. Retrieved from https://bit.ly/2ADNeQO

Keller, K. L. (1993). Conceptualizing, Measuring, and Managing Customer-Based Brand Equity. Journal of Marketing, 57(1), 1-22. Retrieved from https://bit.ly/1N10HO4

Keller, K. L. (2009). Building Strong Brands in a Modern Communications Environment. Journal of Marketing Communications, 15(2-3), 139-155. doi: https://doi.org/10.1080/13527260902757530

Priem, R. (2007, January). A consumer perspective on value creation. Academy of Management Review, 32(1), 219-235. doi: 10.2307/20159289

Romer, P. (2002). When should we use intellectual property rights? American Economic Review, 92(2), 213-216. Retrieved from https://bit. ly/2FeB1Gg

Scolari, C. A. (2009). Transmedia Storytelling: Implicit Consumers, Narrative Worlds, and Branding in Contemporary Media Production. International Journal of Communication, (3), 586-606. Retrieved from https://bit.ly/2SaZ8Zd

Shone, T. (2014, July 25). Hollywood Transformed: How China is Changing the DNA of America's Blockbuster Movies. The Financial Times. Retrieved from https://on.ft.com/2RhIKtI

Shostack, G. L. (1977, April). Breaking free from product marketing. The Journal of Marketing, 41(2), 73-80. doi: 10.2307/1250637

Tennent, C. (2015, May 15). Netflix vs Amazon Prime Instant Video which is best? Which? Retrieved from https://bit.ly/2RAY43J

The Guardian (2003, November 5). BBC3's Fightbox on the Ropes. Retrieved from https://bit.ly/2Ff6UOT 